University for Business and Technology in Kosovo

UBT Knowledge Center

UBT International Conference

2012 UBT International Conference

Nov 2nd, 9:00 AM - Nov 3rd, 5:00 PM

\title{
Sustainable Renovation in Kosova
}

Sadije Kelmendi

University for Business and Technology, sadije.kelmendi@ubt-uni.net

Follow this and additional works at: https://knowledgecenter.ubt-uni.net/conference

Part of the Architecture Commons

\section{Recommended Citation}

Kelmendi, Sadije, "Sustainable Renovation in Kosova" (2012). UBT International Conference. 13.

https://knowledgecenter.ubt-uni.net/conference/2012/all-events/13

This Event is brought to you for free and open access by the Publication and Journals at UBT Knowledge Center. It has been accepted for inclusion in UBT International Conference by an authorized administrator of UBT Knowledge Center. For more information, please contact knowledge.center@ubt-uni.net. 


\title{
SUSTAINABLE RENOVATION IN KOSOVA
}

\author{
MSc. Sadije Kelmendi, \\ Department of Architecture and Spatial Planning, University for Business and Technology, \\ "Lagja Kalabria" p.n. 10000 Prishtine \\ E-mail: sadije.kelmendi@ubt-uni.net
}

\begin{abstract}
The built environment is one of the most obvious examples of the impact of human activity. Globally, buildings have a substantial impact on our energy use and the pollution of our environment. Buildings consume 35-40\% of our primary energy. From that 35-40\% of buildingrelated CO2 emissions, 29\% of that could be cut by 2020 using existing technologies.

Governments around the world are starting to define requirements for sustainable buildings. Targets are being set for reductions in energy consumption and carbon dioxide emissions.

As Kosova faces big energy challenges in both low energy production and at the same time high energy consumption, investing in energy efficiency measures (both in new and already existing buildings) is very important.

This research focuses on sustainable renovation possibility in Kosova, illustrated by a casestudy, more precisely an existing kindergarten building in Prishtina. The majority of these kinds of building were constructed about 30 years ago and apart from the ageing of the façade, roof and windows, the building

standards and material quality regarding energy saving at that time were significantly lower compared to

the one today.

Analysis done to inspect the existing situation is multi-disciplinary. Simulation software used to generate

data for $U$ values and energy demand is Ecodesigner, a GraphisoftArchiCAD add-on.

This research aims to inform the local institutions for the possibilities on reducing energy consumption

and increasing energy independence, to promote a healthy educating environment, to serve as toolfor

teaching about renewable energy and green construction, and finally to function as a pilot kindergarten, a replicable model for future sustainably renovated kindergartens. The results emphasize the big decrease of energy demand along with the increase of the thermal comfort and subsequently CO2 emission decrease. With this it is intended to raise awareness for ecological/economic concerns of existing buildings and contribute that this kind of renovation becomes enforced by law for all old public institutions.
\end{abstract}

Keywords: sustainable building design, renewable energy, energy efficiency, payback time, CO2 emission

\section{Introduction}

The Kosova energy sector faces difficult challenges. The main energy sources for both space and water heating in Kosova are biomass (mainly firewood) and electricity, each accounting for around $40 \%$ of consumption.

The high consumption of firewood results in deforestation, giving rise to adverse environmental impacts. Electricity generated from indigenous lignite is used inefficiently, leading to power cuts and expensive imports of electricity. The situation in the electricity sector is further aggravated by incomplete billing, very low collection rates and high 
technical losses. The highly energy intensive buildings sector of Kosova pays little attention to $\mathrm{EE}^{74}$ and today buildings account for some $40 \%$ of energy demand. If energy consumed in building construction is included, then this number grows to more than $50 \%$.

This is why the building sectoris a key to reducing energy consumption and reducing $\mathrm{CO}_{2}{ }^{75}$ emissions. Kosova is a signatory party to the Treaty for the establishment of the Energy Community (EnC) of South-East Europe that entered into force in July 2006. Within this context, the Government of Kosova remains committed to developing the energy sector in compliance with EnC requirements.

Taking into consideration the three EU standards to be achieved by 2020 , namely to improve EE by $20 \%$, to reduce greenhouse gases by $20 \%$ and to have $20 \%$ of the total energy consumption covered by RES ${ }^{76}$, Kosova drafted the national plan on energy efficiency and took an obligation to improve EE in total energy consumption by $9 \%$ until 2018, thus accomplishing an improvement of approximately $1 \%$ per year. The Commission considers the biggest energy savings are to be made in the following sectors: Residential and Commercial buildings, with savings potentials estimated at $27 \%$ and $30 \%$ respectively, the manufacturing industry, with the potential for a $25 \%$ reduction, and transport, with the potential for a $26 \%$ reduction in energy consumption.

\section{Objectives}

"7 percent of all energy consumed in America is used to light our homes and our businesses...from lighting to windows, heating to cooling, smart sensors and controls...we can make our buildings up to 80 percent more energy efficient"

\section{Barack Obama}

The aim of this research is to analyze the possibility of sustainable renovation application, as well as showing advantages of the same from economical/ecological and comfort point of view. It focuses on public kindergartens that have none or poor thermal insulation which degrades the day-care conditions in a kindergarten.

Main objectives of this study are:

-Conduct an analysis including all energetic, functional and architectural deficits of the existing building;

-To draft a renovation design, transforming the building completely in order to raise the overall quality of the building - from energetic, functional, design, ecologic (material) to the user comfort point of view;

- To integrate innovative renewable energy technology;

-To analyze cost-efficiency and the payback time of sustainable renovation measures;

-To calculate how much energy could be saved, if all public kindergartens in Kosova would be renovated;

The purpose is to present new sustainable materials and techniques/design for reconstruction of existing building in order to raise society's awareness on sustainability in region of Kosova.

\section{Research methodology: Case study kindergarten "Fatosat"}

"Solutions which meet the needs of today without compromising the ability offuture generations to fulfil their own needs"

Christel Vaenerberg

\subsection{Data collection}

This section deals with analys is of all energetic, functional and architectural deficits of the building.

In order to discover these deficits, a detailed analys is of the materials used for the existing building and its layout had to be carried out. An important role plays also the behaviour of occupants and all the heat generating electrical appliances, called internal gains.

Table 1. Documentation data for surveying (Survey 2011-S.Kelmendi)

\footnotetext{
${ }^{74}$ Energy Efficiency

$751 \mathrm{kWh}$ of electricity produced from lignite produces $1,0-1,6 \mathrm{~kg}$ of emitted $\mathrm{CO}_{2}$.

${ }^{76}$ Renewable Energy Sources
} 


\section{Size}

Building form

Distance from neighboring buildings

Children and staff members

Cost for heating
Type of heating
Energy consumption

Energy consumption

Number of rooms and spaces

Internal conditions

Light gain

\section{Overall corpus dimensions}

Building project

Shadow calculation

Total number of occupants

Construction layers Walls, Slabs, Roof

Wood, Coal, Electrical, Gas, other

Data from KEK

Heated and non heated

Occupancy behaviour

Types and position of lighting

\subsection{Climate data}

The climatic data for the simulations have been generated by NASA Atmospheric Science Data Center for the city of Prishtina. Pristina is located at the geographical coordinates $42^{\circ} 40^{\prime} 0^{\prime \prime}$ North and $21^{\circ} 10^{\prime} 0^{\prime \prime}$ East at an altitude of 652 meters above sea level (Wikipedia 2011). Prishtina has a humid continentalclimate with very warm summers and cold and often snowy winters.Data generated by NASA ASDC ${ }^{77}$ were used because it was not possible to find detailed meteorological data from the local government. The local institutes provided only monthly mean values $\left(\mathrm{IHMK}^{78} 2010\right)$ of temperatures and they were insufficient for a simulation which required statistics based on an hourly data. The results of weather data generated by NASA ASDC came up close to the actual weather conditions found in the region as presented in the following graph:

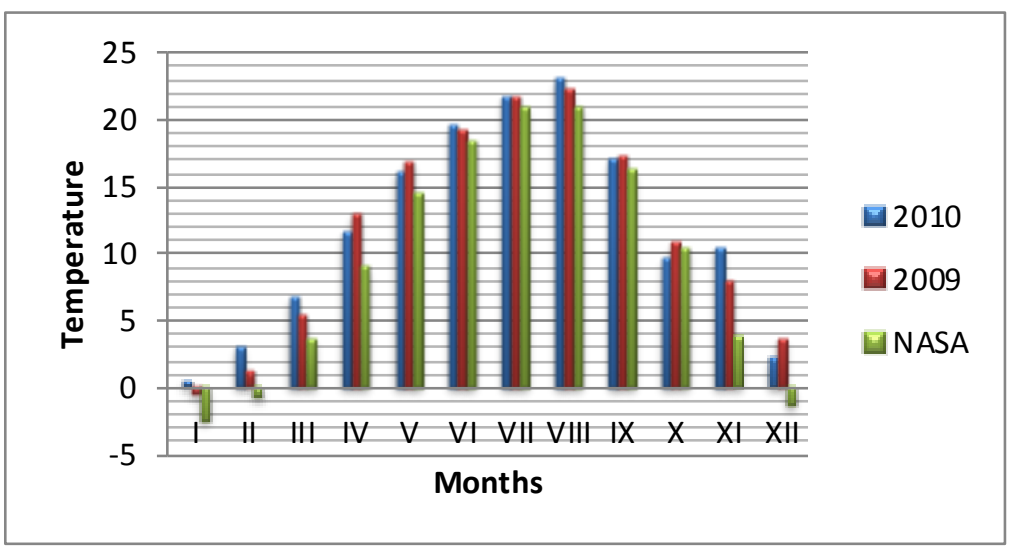

Figure 22. Average Temperatures in Prishtina last 2 years (IHMK/NASA)

\subsection{Evaluation with Graphisoft Ecodesigner}

Graphisoft EcoDesigner is an integrated, easy-to-use energy evaluation tool for architects. EcoDesigner is an addon to ArchiCAD. EcoDesigner enables architects to compare energy consumptions, monthly energy balances, operation costs, carbon emissions and other indicators to inform the design process and make the best design choices regardless of the climate where the building is built or renovated. Using Graphis oft EcoDesigner architects can

\footnotetext{
${ }^{77}$ NASA Atmospheric Science Data Center

${ }^{78}$ Institute of Hydrometeorology of Kosova
} 


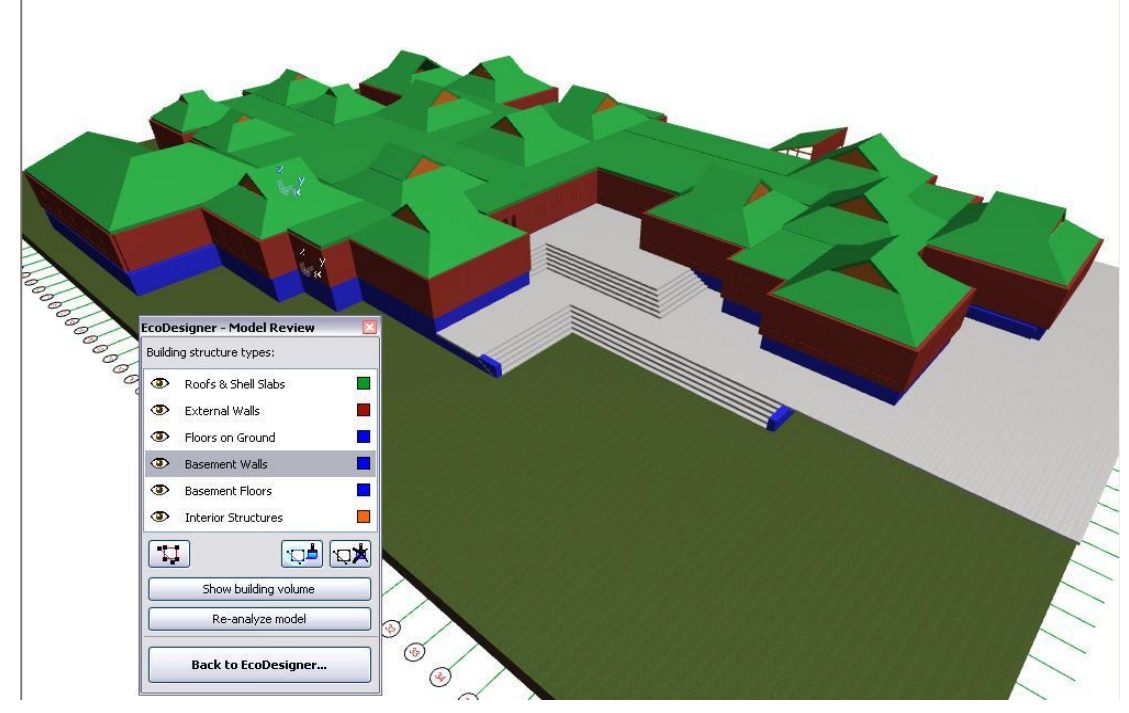

Figure 23. Model simulation of building shell with Ecodesigner (Survey 2011)

Providing invaluable feedback on the building's energy performance means the architect can make better decisions on how to conform to regulations and satisfy the interests of the client and the operator of the building.

\subsection{Existing situation of the building}

\subsubsection{Site plan and surroundings}

The building is located in the south-eastern part of the city, in the neighborhood called Ulpiana, street "Zija Shemsiu". It is surrounded by residential multi-storey blocks and lots of trees, especially in north-eastern and southern part.

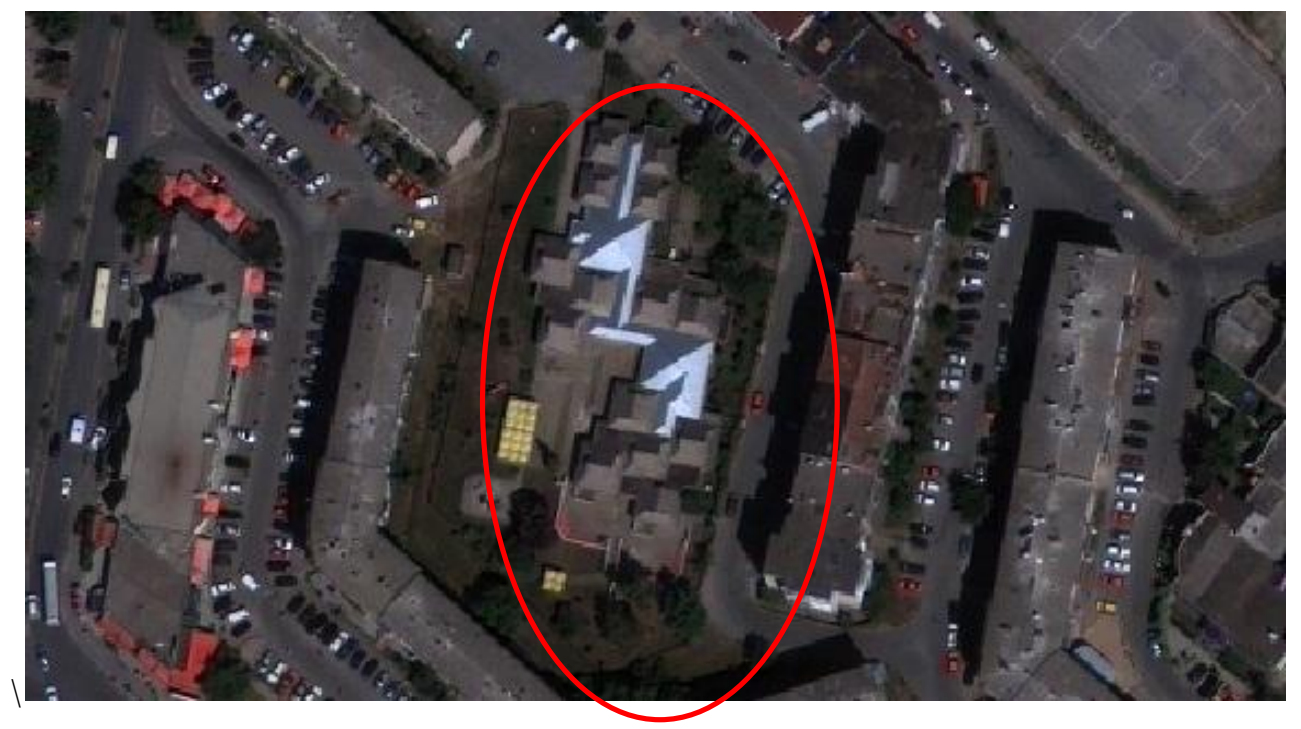

Figure 1. Kindergarten surrounding ortophoto 2010 ( Prishtina Municipality, Department of Urbanism, Cadastre, Construction and Environment Protection)

This building is built in 1978. Due to non-insulation and big height of corridors and common spaces, the temperatures in them are quite low and not comfortable. 


\subsubsection{Occupants and operation}

The kindergarten operates from September $1^{\text {st }}$ to July $31^{\text {st }}$, Monday to Friday and from 6:30 am to 17:00 pm. The total number of children attending the kindergarten is 250 in addition to 39 staff members. There is a big demand for child care, but the existing space is completely filled and cannot accept any additional children. Average number of babies (1-2yrs. old) per group is 14, and for children (2-6 yrs. old) is 20. The dining area doesn't suffice needs for all children, thus children have to eat in the classes/rooms.

\subsubsection{Building layout}

It is a 1 floor building with an area of $1480 \mathrm{~m}^{2}$. There are 11 classrooms and plus 4 common spaces. The site visit was performed in different time periods, as well as short energy audits and measurements of all the spaces of the building. Table 6 presents the geometric data of the existing situation, with reference to its gross total floor area, the number of the windows and doors and their area, the external wall area, the internal height of the building and the calculated volume.

Table 2. Geometric figures for insulation surface (Survey 2011-S.Kelmendi)

\begin{tabular}{|l|r|r|r|}
\hline & Height $(\mathbf{m})$ & Perimeter $(\mathbf{m})$ & Surface $\left(\mathbf{m}^{2}\right)$ \\
\hline Walls & 3.5 & 324.5 & 1135.75 \\
\hline $\begin{array}{l}\text { Windows } \\
\text { \& doors }\end{array}$ & & & 262 \\
\hline \multicolumn{3}{|c|}{ Total insulation surface } & $\mathbf{8 7 3 . 7 5}$ \\
\hline
\end{tabular}

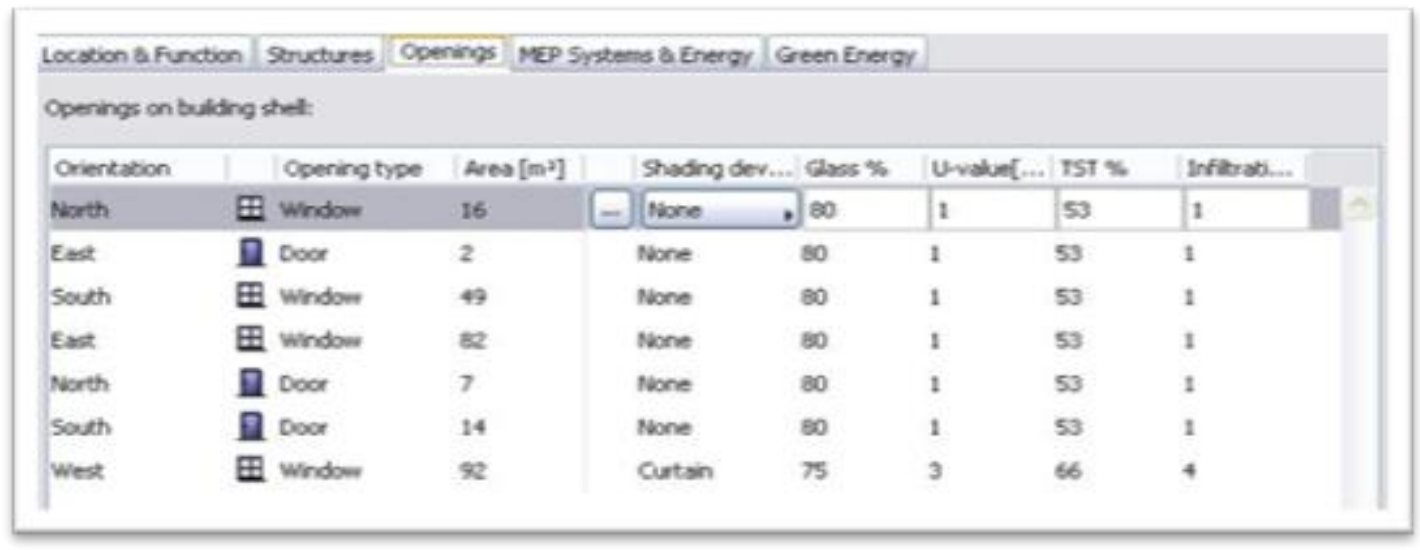

Figure 24. Window analysis with Ecodesigner (Survey 2011-S.Kelmendi)

The interior of the building is in a quite good condition and very well organized. Except the demand for more space from potential children to be enrolled, it suffices the current needs. It is important to mention that the low temperatures in common areas makes these otherwise cosy areas very uncomfortable, and subsequently unusable during cold season.

\subsubsection{Materials}

The walls are all non-insulated and made of brick. The windows have been replaced recently, instead of old wooden ones, now there are plastic double glazed ones in place. The roof tiles are made of asbestos, which usage in the time the object was built (1978) was allowed. Now it is forbidden as it is found that Asbestos has been classified as a known human carcinogen (a substance that causes cancer) by the U.S. Department of Health and Human Services, the EPA, and the International Agency for Research on Cancer. 


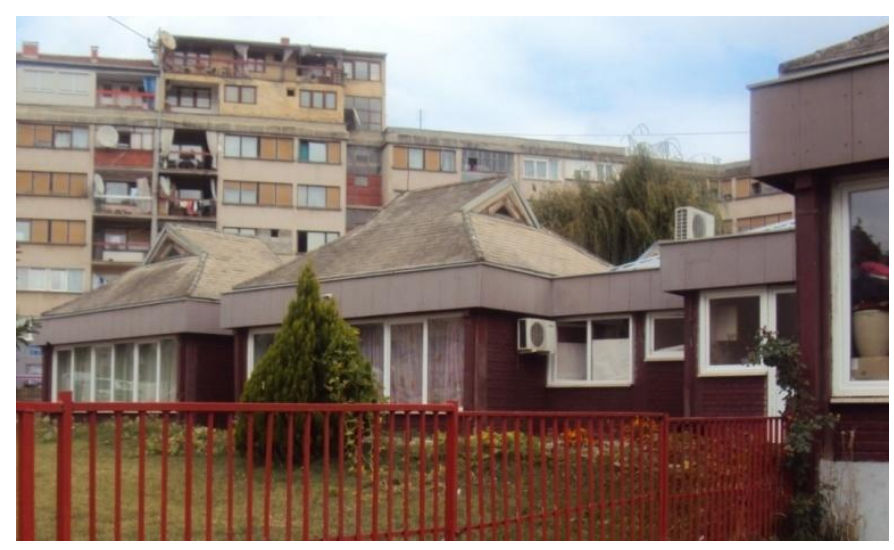

Figure 2. Exterior material of Fatos at kindergarten (S.Kelmendi)

People may be exposed to asbestos in their workplace, their communities, or their homes. If products containing asbestos are disturbed, tiny asbestos fibres are released into the air. When asbestos fibres are breathed in, they may get trapped in the lungs and remain there for a long time. Over time, these fibres can accumulate and cause scarring and inflammation, which can affect breathing and lead to serious health problems. The parquet on floor is quite old and not polished. The radiators are old and inefficient.

\subsubsection{Energy consumption}

As can be seen on the chart below, the kindergarten spends tremendous amount of money in electricity every ye ar, especially in last year, up to $2200 €$ per month (January) and $12.000 €$ per year (Fig.18).

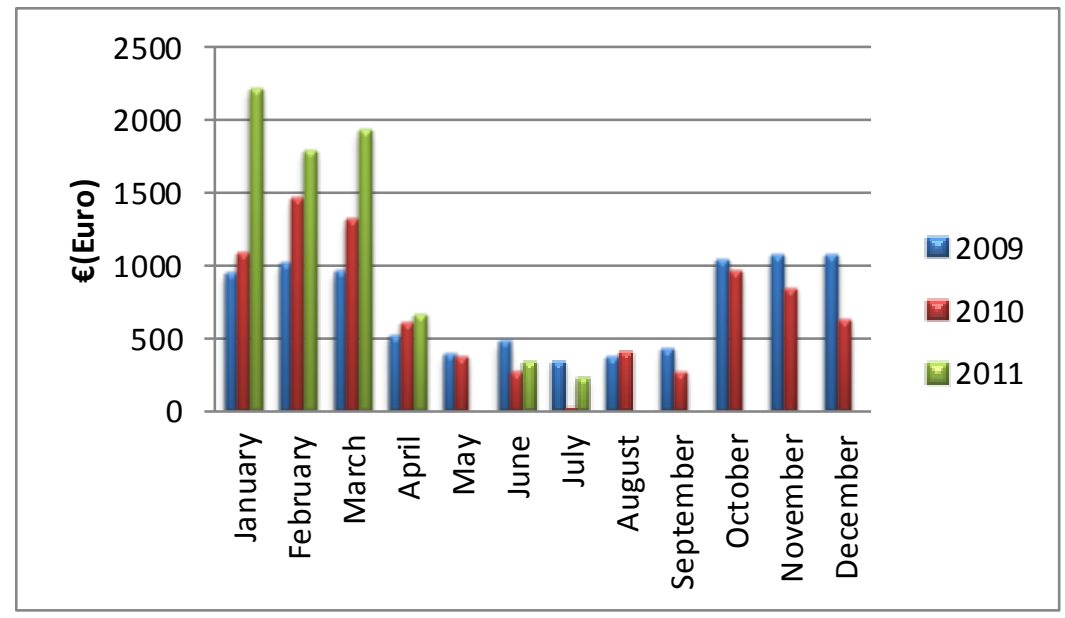

Figure 25. Monthly electrical energy consumption in $€$ (data from KEK bill)

The electrical energy consumed by the school is excessive and is not justified by the existing energy consuming devices. 


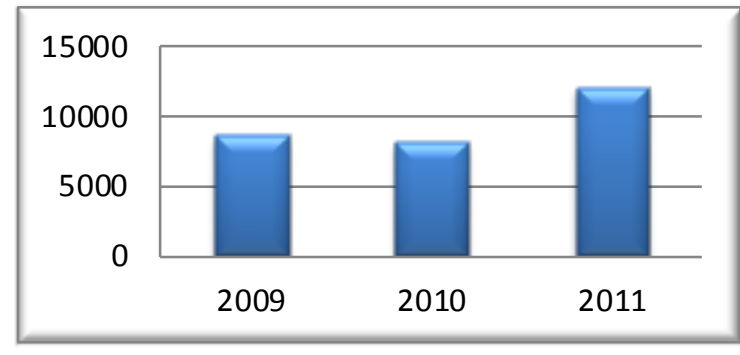

Since the energy consumption in $\mathrm{kWh}$ was impossible to provide, an approximate calculation with the price data was performed. If $0.08 € / \mathrm{kWh}$ is we taken as the approximate tariff, it results that energy consumption of the building is $101.625 \mathrm{kwh}$ (100MWh) for year 2010, respectively 150 MWh for the year 2011. The total energy consumption per square meter of schoolspace is $101 \mathrm{kWh} / \mathrm{m}^{2}$ with existing poor thermal conditions (heating only classrooms and offices but not corridors, playrooms and events rooms).

Figure 26. Annual energy consumption ( $€$ )-(S.Kelmendi)

The main share of energy costs takes the heating. Since the district heating systemis not operating last years, kindergarten management had to find alternative improvised ways to heat the spaces, especially child ren classrooms. Now each of 11 classrooms has 3 different heating devices, besides the ones in administrative offices. Lighting fixtures are half incandescent, half fluorescent. Boiler is also working on electricity.

\section{Improvements}

In order to make the object as sustainable as possible, several improvements are proposed.

\subsection{Architectural improvements}

The final measurements are used in order to compare them with the initial ones and to create, in ArchiCAD, the final "existing" plan view of the ground floor and 3D presentation of the building, in all directions (Figures 21 to 23). Enlargement of space is proposed, which besides fulfilling the needed capacities contributes to making the building's layout more compact. Adjustable window awnings (canopies) will be installed in the windows on the south facade. They will protect the southern facade from overheating in summer, but will allow winter sun to enter into the depth of the rooms.

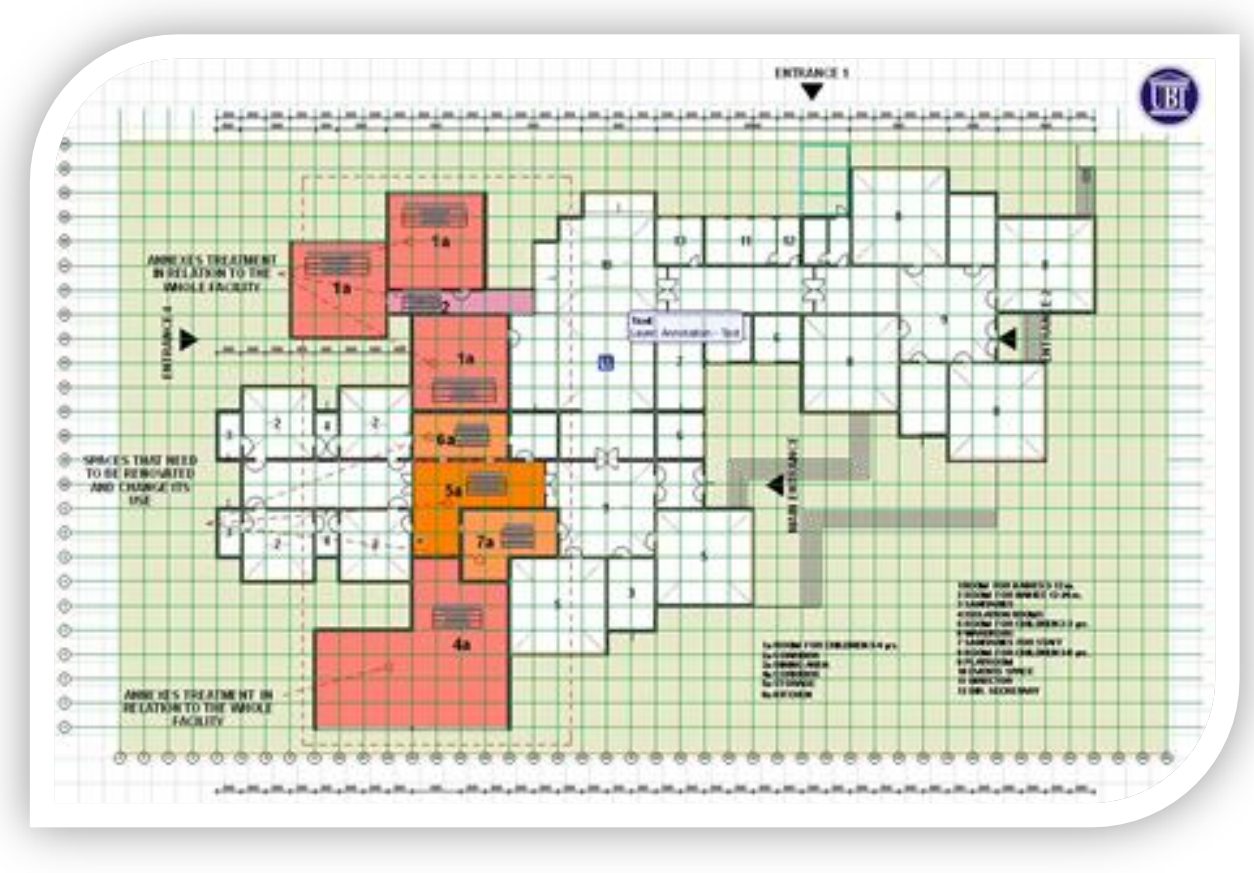

Figure 3. Floor plan of the renovation project (S.Kelmendi) 
The investment for the 6 canopies is estimated at $2.000 €$.As the insulation of the building needed to be performed, it is proposed that after the mortar and net, to decorate the building with different colour ecological paints. In that way the building besides increasing the thermal resistance, increases also the attractiveness ecological contribution.

Figure 4. 3D visualization of the renovation building(S.Kelmendi)

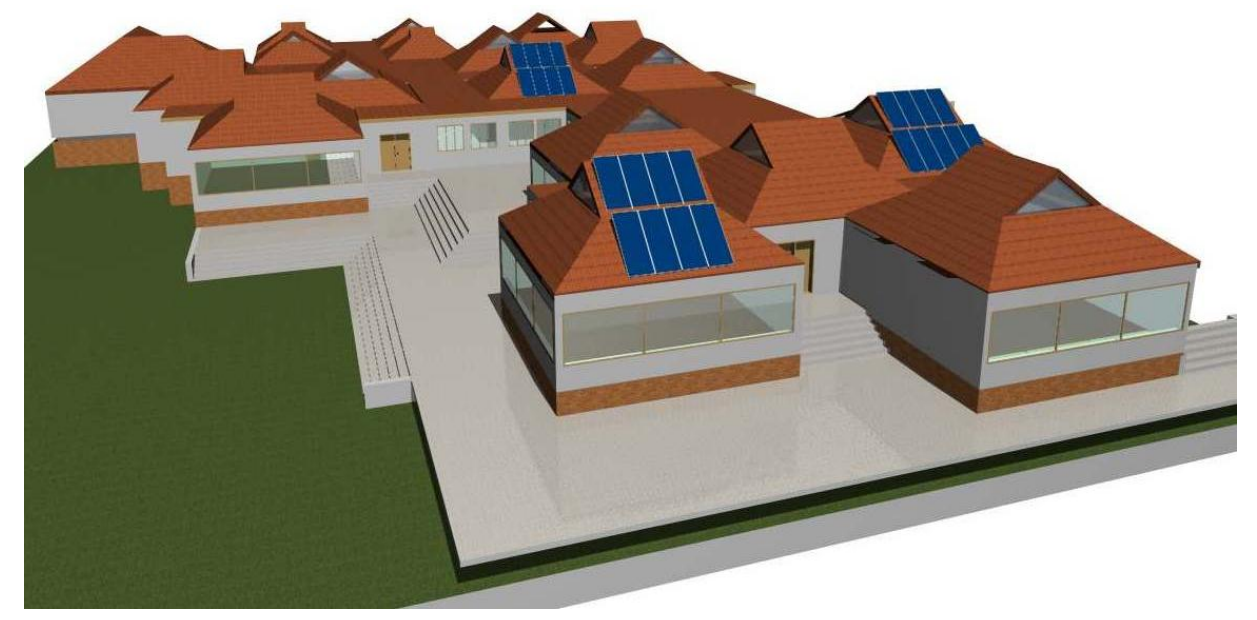

\subsection{Energetic improvement}

\subsubsection{Applying thermal insulation}

Leakage or loss of thermal energy there through walls, roof, and floor plate, if the inner surface layer does not contain adequate for avoiding the leakage or "air tight layer"

This leak raised energy consumption, thermal recovery of losses. The easiest, fastest and the most effective way to reduce costs of heating - and also of cooling in summer - is to apply a suitable thermal insulating protection. It is proposed to apply insulation and color materials which are environmentally friendly because they will also help to reduce the buildings carbon footprint. For the thermal insulation, EPS board is chosen. It has proven cheaper and its thermal performance is better than XPS' one. According to material's characteristics, if applied with brick (as it is our case), U-value is $0.30 \mathrm{~W} / \mathrm{m}^{2} \mathrm{~K}$. Besides walls, as the floor will be in construction due to heating systemchange, placement of also floor thermal insulation is proposed, as it would contribute to the efficiency of heating systemand of course comfort increase for children.

\subsubsection{Using renewable energy sources:Installing Hybrid Photovoltaic-Thermal collectors}

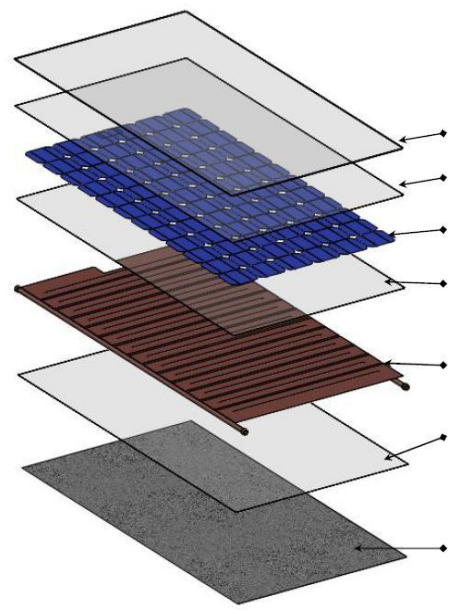

In order to increase the efficiency of the building, it is proposed to install new hybrid Photovoltaic-Thermal panels on the roofs, produced for the first time by Turkey-based solar company Solimpeks. Both electricity and usable thermal heat are generated at the same time from one panel. These systems combine a photovoltaic cell, which converts electromagnetic radiation (photons) into electricity, with a solar thermal collector, which captures the remaining energy and removes waste heat from the PV module.. Half of the building roofs are oriented south-north and half of them east-west. The "9" south-north roofs are proposed for installation of solar panels, more precisely only the roof's halves oriented toward south. To store the electricity, normal batteries, or a hydrogen fuel cell, could be used. Additionally, the PV-T panels can be used in conjunction with other terhnolnaias to furtharanhannasuarrer affinianny if desired. It is proposed to c Figure 27. PV-T layers (Solimpeks) m.

\subsubsection{Geothermal heating}

Excess heat produced by the PV-T panels can be stored in the ground for use at a later time $=>$ summer heat can be used into the winter to maximize energy use. Consistent year-long underground temperatures are what make geothermal heat pumps work well in cold climates. A typical geothermal heat pump employs a closed loop of piping 
containing a non-toxic liquid that circulates between the building and underground. The biggest advantages of geothermal heating systems are low cost heating (you can save up to $80 \%$ compared to fossil fuels) and a small amount of electrical energy compared to conventional heating systems. A geothermal heat pump requires a minimum amount of space for the outdoor coil or wells. As the kindergarten lot has enough outdoorspace, this is not a problem. One underground loop can support many small indoor heat pump units, making it an ideal choice for schools and other buildings where heating and cooling by zone is desirable.

\section{Environmental considerations}

The improvement of the environmental performance of the building has an important environmental implication in the sense that less fuel is consumed for the same level of thermal comfort and thus less combustion emissions are released to the atmosphere.

By evaluation done in Ecodesigner, the proposed interventions would result in $\mathrm{CO}_{2}$ reduction of little more than 245 tons per annum. The environmental benefits in the form of atmospheric pollution reduction as a result of the energy saving interventions, once installed, will be permanent provided that the energy systems are maintained properly and work according to their specified performance. All of the above is non-hazardous was te that nevertheless needs to be collected and disposed off to designated areas in cooperation with the local authorities. Reuse of waste should be encouraged when such opportunity arises, i.e. for glass panels that survive the replacement works. Insulation panels (EPS and XPS) can be recycled in many ways once they come to the end of its life. Furthermore, the proposed materials for insulation are environmentally friendly. Last, but not least, the materials and technology are chosen from local market and local companies that anyway import goods from the Balkan's region. The reas on lies again in sustainability, in order to avoid additional transportation costs and by that, cause $\mathrm{CO} 2$ emis sions and consequently pollution.

\section{DISCUSSION}

\subsection{Estimating pv-t system size and cost}

In this section are derived the systemspecifications by determining the load, available sunlight, and the size of the PV array and battery bank needed. In the second section, the system specification is converted into a cost for the PV-T system. The detailed load determination is performed by calculating "watts" of each of appliances with hours they operate per day.

Table 3. Kindergarten "Fatosat" electrical appliances and run times (Kelmendi 2011)

\begin{tabular}{|l|r|l|r|r|}
\hline Appliance & $\begin{array}{l}\text { AC or DC } \\
\text { watts }\end{array}$ & $\begin{array}{l}\text { Hours } \\
\text { Used/Day }\end{array}$ & Quantity & $\begin{array}{l}\text { Watt } \\
\text { hours/Day }\end{array}$ \\
\hline Computer & 75 & 6 & 5 & 2250 \\
\hline $\begin{array}{l}\text { Computer } \\
\text { Monitor }\end{array}$ & 150 & 6 & 5 & 4500 \\
\hline $\begin{array}{l}\text { Lights, Compact } \\
\text { fluorescent }\end{array}$ & 20 & 3 & 63 & 3780 \\
\hline Television & 300 & 2 & 6 & 3600 \\
\hline Dishwasher & 1200 & 2 & 2 & 4800 \\
\hline Total & & & 18930 \\
\hline
\end{tabular}

The amount of useful sunshine available for the panels on an average day during the worst month of the year is called the "insolation value." According to the Energy Regulatory Office (2011) average solar insolation values for Prishtina are $4.4 \mathrm{hrs} /$ day of tilted panel. So, for a PV systempowering loads that will be used every day, the size of the array is determined by the daily energy requirement (Tab.8) divided by the sun-hours per day.

18930Wh: $4.4 \mathrm{~h} / \mathrm{day}=4302 \mathrm{~W}$ att

According to the local market prices, a hybrid panel which provides $175 \mathrm{~W}$ of electric energy and $750 \mathrm{~W}$ of thermal energy is $1200 €$. The number of panels needed to produce this energy is 25 which when multiplied by 1200 results in $30000 €$ of investment. Regarding hot water, users' number is very important. Calculation is shown in the table below:

Table 4. Thermal energy demand and cost calculation (Kelmendi 2011) 


\begin{tabular}{|l|r|}
\hline Number of us ers & 300 \\
\hline Number of 1/user & 15 \\
\hline Total number of 1/day & 4500 \\
\hline Design reheat time (h) & 2 \\
\hline Total power input (W/day) & 9000 \\
\hline
\end{tabular}

To calculate number of panels needed to cover thermal energy demand, the total amount is divided by 610 , which is the capacity for the PV-T panels.

Panel size: $86 \mathrm{~cm} \times 166 \mathrm{~cm}=1.43 \mathrm{~m}^{2}$. Roof area covered by hybrid panel is: $25 \mathrm{x} 1.43=35.75 \mathrm{~m}^{2}$.

\subsection{Estimating geo-thermal system size and cost}

A closed-loop vertical systemcan be installed in the "Fatosat" kindergarten, consisting of two 17-kWe ground geothermal heat pumps, to cover the heating and possible cooling loads of the building. This will be obtained by drilling max 10 holes in the backyard of the kindergarten. The total cost is estimated at $60000 €$ without tax, including the heat pump systemand the system for heating the building (floor heating, circulating pumps, etc).

\subsection{Economic appraisal of interventions}

In this section the total energy savings and the corresponding financial benefit are calculated and presented in table 10. In table the simple payback period and the IRR is presented for each intervention and for all interventions applied simultaneously. Most of the applications have relatively short payback periods. The IRR is the discount rate for which the total profit generated by an intervention, once discounted, equals the initial investment. The IRR measures the profitability of the investment. The higher the IRR, the intervention is considered more profitable. The calculated IRRs for all interventions indicate that the proposed interventions are all profitable money wise, since all exceed anticipated discount rates at present money markets. The only requirement to continue obtaining the estimated energy savings over several years, an annual maintenance schedule is absolutely necessary.

Table 5. Economic investments and savings (Kelmendi 2011)

\begin{tabular}{|l|r|r|r|r|r|r|r|}
\hline Intervention & Surface & $\begin{array}{c}\text { Unit Cost } \\
(\boldsymbol{\epsilon} / \mathbf{m} \mathbf{2})\end{array}$ & $\begin{array}{c}\text { Total Cost } \\
(\boldsymbol{\epsilon})\end{array}$ & $\begin{array}{c}\text { Energy } \\
\text { Saving } \\
\mathbf{( k W h )}\end{array}$ & $\begin{array}{c}\text { Net Profit } \\
(\boldsymbol{\epsilon})\end{array}$ & $\begin{array}{c}\text { Payback } \\
\text { Period } \\
(\text { years) }\end{array}$ & $\begin{array}{l}\text { Internal } \\
\text { Rate of } \\
\text { Return }\end{array}$ \\
\hline External Wall & 873.76 & 25.00 & 21,844 & 84,120 & $7,570.80$ & 2.9 & $35.61 \%$ \\
\hline Geo-thermal pump & 1.00 & $60,000.00$ & 60,000 & 110,000 & $9,900.00$ & 6.1 & $16.93 \%$ \\
\hline Solar Collectors & 36.00 & 830.00 & 29,880 & 35,000 & $3,150.00$ & 9.5 & $12.11 \%$ \\
\hline Accumulative & & & $\mathbf{1 1 1 , 7 2 4}$ & $\mathbf{2 2 9 , 1 2 0}$ & $\mathbf{2 0 , 6 2 0 . 8 0}$ & $\mathbf{5 . 4}$ & $\mathbf{1 9 . 2 3 \%}$ \\
\hline
\end{tabular}

From the above table one can see that the payback time of investments is 5 years.

\subsection{Awareness raising through sustainability measures}

Electricity from the sun is a fascinating idea and solar electric panels capture the public imagination mo re than any other renewable energy technology. These public buildings are good examples of how investing in energy saving measures helps the environment as well as the economy, with a short paybackperiod. In this way are presented new sustainable materials and techniques/design for reconstruction of existing building in order to raise society's awareness on sustainability in region of Kosova. With this it is intended to also contribute that this kind of renovation becomes enforced by law for all old public institutions.

\section{Conclusion}

In conclusion, it is proposed that the total investment is implemented, including the new heating systemand the shading devices, in order to have an integrated state-of-the-art intervention and provide the appropriate comfort to the children and employees. The total cost of the interventions proposed is approximately 111.726 Euro. The 
expected payback period, without considering financial costs, is estimated at 5.5 years and the corresponding IRR is equal to $21 \%$. Thus, all the proposed investments are viable and are expected to produce financial profits in a short period of time ( $\max 6.5$ years). All this having in mind that after the renovation all kindergarten surface will be usable, including the common spaces. The proposed interventions would result in $\mathrm{CO}_{2}$ savings of little more than 245 tons per annum. As these buildings have been built long time ago and with no or insufficient thermal insulation and also because there is a big number of such building, a pro-active approach is strongly propose to improving their energetic performances in order to make the living environment more sustainable and ecologic, subsequently. In addition, the proposed interventions with the corresponding energy saving will improve the security supply of energy for Kosova. Last, but not least, this would contribute to achieving the set targets 20-20-20 of European Union.

\section{References}

1. An EU-funded project managed by the European Agency for Reconstruction, January 2009; "Study On Energy Efficiency Measures In Public Buildings- Gijn Gazuli Technical High School"; Detailed Audit Report 2. Daniel, Marcy L., 2003; "The January 2003 Construction Sector Assessment Report For Kosova”; CHF International-USAID, Editor: Wayne Meyer, 2003, Dukagjini Ltd. Peja/Kosova

3. European Agency for Reconstruction through BCEOM, 2003; "Institutional Evelopment For Implementation Of An Energy Efficiency Programme In Kosova"; Project fact sheet

4. "Energy data's for Kosova for the period 2002-2008", Publication, Statistical Office of Kosova (SOK)

5. Kajtazi-Thaçi, Ardita 2008; “Analizë E Gjendjes Së Tanishme Në Edukim Parashkollor Në Kosovë”, MASHT 6. ISLAMI, Agron, 2007; “A Systematic Approach To Thermal Adaptation Of Detached Single Family Buildings In Kosovo" - Master thesis

7. Andreas T. Wolf, 2011; "Sustainable Renovation of Buildings - A Model Applicable to China? ", International Journal of Energy Science, IJES Vol.1 No.1 2011 PP.58-61, viewed May 2010, http://magazine-

e.ubs.com/en/home/your-home/sustainable-renovation.aspx

8. European Commission Liais on Office to Kosova, Press Releases, 2011; "EU improves energy efficiency of public buildings in Kosova municipalities", viewed June 2011

9. Susan Roaf, 2010; MSc. in Energy Efficient Building- Examples Of Sustainability Teaching”, Oxford School of Architecture, http://www.heacademy.ac.uk/assets/cebe/Documents/projects/SIGs/Dr_S_Roaf_Oxford_Brookes.pdf

10. Graphis oft, 2011; “Ecodesigner-flyer”, viewed December 2010, http://download.graphisoft.com/ftp/marketing/ed/ED14_Flyer_A4_LQ.pdf

11. Zyra e Rregulatorit per Energji, 2010; “Tarifat e ngrohjes qendrore të NQ Termokos sh.a. për sezonin e ngrohjes 2010/2011”, viewed January 2011,http://ero-ks.org/Vendimet/Shqip/Tabela_NQ_Termokos_2010_2011.pdf

12. Republic of Kosova, Ministry of Public Services, Statistical Office of Kosova, 2010; "Education Statistics 2009 - 2010", viewed March 2011, http://esk.rks-gov.net/ENG/publikimet/doc_view/907-education-statistics-2009-

2010?tmpl=co mponent\&format=raw

13. As sembly of Kosova, 2004; "ENERGY LAW", Law no. 2004/8, http://www.as sembly-

kosova.org/common/docs/ligjet/2004_8_en.pdf 